\title{
Serum Testosterone Level and Semen Indices in Sulfur Mustard Exposed Men: Comment on "Sperm Chromatin Structure Assay Analysis of Ira- nian Mustard Gas Casualties: A Long-Term Outlook"
}

\author{
Kamyar Ghabilia Mohammadali M. Shoja ${ }^{\mathrm{b}} \quad$ Samad E.J. Golzaric Khalil Ansarin ${ }^{\mathrm{b}}$ \\ ${ }^{a}$ Medical Philosophy and History Research Center; ${ }^{\text {} T u b e r c u l o s i s ~ a n d ~ L u n g ~ D i s e a s e ~ R e s e a r c h ~ C e n t e r ~ a n d ~}$ Physical Medicine and Rehabilitation \\ Research Center, Tabriz University of Medical Sciences, Tabriz, Iran
}

Dear Editors,

We read with great interest the article by Safarinejad [1], which investigated an association between sulfur mustard (SM) exposure and sperm DNA damage using sperm chromatin structure assay on SM-injured and non-SM-injured infertile and fertile men. Accordingly, spermatozoa from SM-injured subjects had more abnormal chromatin than their non-SM-injured counterparts [1]. This article is quite interesting as the relationship between SM exposure and sperm DNA integrity has not been hitherto reported in the literature [1-3]. However, there are 2 controversial findings in the study by Safarinejad. In table 1 of the results section, Safarinejad recorded $122.7 \mathrm{nmol} / \mathrm{l}$ as the mean value of serum testosterone level in non-SM-injured healthy fertile men (group 4 of the study). In contrast, the mean serum level of testosterone in other studied groups including SM-in- jured infertile and fertile men and non-SM-injured infertile individuals was about $12.6 \mathrm{nmol} / \mathrm{l}$. Nonetheless, under serum hormones subheading, insignificant difference was concluded among the study groups with regard to this serum hormone [1]. The mean serum level of testosterone in group 4 of the study seems irrelevant to the reference values (i.e. 9.36-37.10 nmol/l) as well [4].

The second ambiguous finding of the study is under semen values subheading in the results section. Safarinejad indicated that the mean ejaculate volumes in non-SM-injured controls and SM-exposed patients were not statistically significant. Nevertheless, statistical analysis of this comparison yielded $\mathrm{P}$ value of 0.01 which is less than 0.05 (indicative of the statistical significance) [1]. Since no similar studies are currently available in the SM-related literature, we therefore suggest the author elucidate these discrepancies in the results section to provide more accurate conclusions for the clinicians and researchers in this regard.

\section{References}

1 Safarinejad MR: Sperm chromatin structure assay analysis of Iranian mustard gas casualties: a long-term outlook. Curr Urol 2010;4: 71-80.

-2 Ghabili K, Agutter PS, Ghanei M, Ansarin K, Shoja MM: Mustard gas toxicity: the acute and chronic pathological effects. J Appl Toxicol 2010;30:627-643.
3 Ghabili K, Agutter PS, Ghanei M, Ansarin K, Panahi Y, Shoja MM: Sulfur mustard toxicity: history, chemistry, pharmacokinetics, and pharmacodynamics. Crit Rev Toxicol 2011; 41:384-403.
4 Kratz A, Ferraro M, Sluss PM, Lewandrowski KB: Case records of the Massachusetts General Hospital. Weekly clinicopathological exercises. Laboratory reference values. $\mathrm{N}$ Engl J Med 2004;351:1548-1563.

\section{KARGER}

Fax +4161306 1234

E-Mail karger@karger.ch

www.karger.com
(C) 2012 S. Karger AG, Basel

$1015-9770 / 12 / 0062-0112 \$ 26.00 / 0$

Accessible online at:

www.karger.com/cur
Kamyar Ghabili, MD

Medical Philosophy and History Research Center

Tabriz University of Medical Sciences

Tabriz (Iran)

Tel/Fax +989144106136, E-Mail kghabili@gmail.com 